\title{
Tres temas de la imagen de la Conquista y la Colonización
}

\author{
Martha Barriga Tello \\ Departamento Académico de Arte
}

【J na de las consecuencias intelectuales del descubrimiento de América en Europa y en España en particular, fue el "remozamiento de la utopía" que ya no se proyectó a un lugar soñado sino a uno "posible", cuya localización minimizó la conciencia de la difícil situación europea del momento. Inicialmente no se dió importancia al decubrimiento de nuevas tierras pero, posteriormente, se convirtí́ en receptáculo y reflejo de las aspiraciones más extremas. La Utopía de Tomás Moro y las doctrinas de Erasmo de Rotterdam encontraron vía fértil en América como demostrarían los libros -uno de ellos el Enchiridion o Manual del caballero cristiano- que figuraron en la biblioteca del obispo Vicente de Valverde en 1542 (Hampe, Teodoro. Bibliotecas privadas en el mundo colonial. Frankfurt-Madrid, 1996, 85) Las doctrinas de Erasmo déspertaranceñtuslàsmoipor las posibilidades que abría para propagar el Cristianismo y establecer un nuevo tipo de sociedad en los territorios occidentales. Esta propuesta fracasó por la intolerancia religiosopolítica de los acontecimientos en el viejo continente y las secuelas que tuvo en el nuevo. Como escribiría Luis Vives, uno de los pensadores más reconocidos en su época: "Atravesamos unos tiempos calamitosos en los cuales no es posible hablar ni callar sin peligro" (Pedro, Valentín de. América en las letras españolas del Siglo de Oro. Buenos Aires, Editorial Sudamericana, 1954, 43; Bataillón, Marcel. Erasmo y España. México, Fondo de Cultura Económica, 1982, passim). Paradójicamente coexistió con las ideas utópicas una actitud de negación acerca del mismo fenómeno. 
Esta posición inicial frente al descubrimiento de América se extendió a vastos sectores de la sociedad española. Entre los estudiosos de la pintura de los siglos XVI y XVII ha llamado la atención la ausencia del tema americano. No se trató exclusivamente de negar formalmente al indígena americano esterotipándolo. También -y menos explicable en un país orgulloso de sus gestas- se evitó representar aquello vinculado a las campañas de exploración y de colonización, así como de resaltar a sus protagonistas. No hubo preocupación entre sus compatriotas peninsulares, más o menos vinculados al hecho, por preservar su memoria a través del arte. Tampoco hubo entre los actores voluntad en contrario. Contamos con un casi nulo repertorio de fuentes documentales gráficas contemporáneas que nos informen de aspectos puntuales de esta campaña y, por ende, del punto de vista plástico de sus responsables, así como de su interés de mostramiento y la visión de sí mismos. Al respecto, y a propósito de la Virgen de los navegantes que entre 1530 y 1540 pintó Alejo Fernández por encargo de la Casa de Contratación de Sevilla, Jonathan Brown ha hecho notar que aparece la flota con destino a las Indias lista a emprender el viaje pero que los navegantes, totalmente protegidos bajo el manto misericordioso de la Virgen, no han podido ser identificados a pesar de suponerse que eran representaciones de personajes reales (Brown, Jonathan La Edad de Oro de la pintura en España, Madrid, Nerea, 2a. ed. 1991: 28-29). En un estudio de Bartolomé y Lucile Bennassar se informa que Alicia Gould Quincy ha reconocido a 87 de los 100 personajes del cuadro (1492 ¿un mundo nuevo? Madrid, Nerea, 1992, 2099. Pot la fechà en la quefue realizada la pintura -y fallecidos los protagogistas $\supseteq$ Redría interpretarse el, hecho como significativo de una empresa que era considerada colectiva por corresponder a la responsabilidad política de la corona española, en consecuencia no se destacaban los individuos. La falta de fuentes también puede ejemplificar la despreocupación de los personajes por recibir el crédito que merecían. Sería sorprendente esta última opción pues conocemos hoy que las peticiones reivindicativas aparecieron desde muy temprano, ya que esta fue una campaña que comprometió el patrimonio de los protagonistas antes que los del Estado. El ocultamiento es un asunto al que no se le encuentra una explicación satisfactoria, con menor razón si se indaga en la historia del arte y en otras disciplinas independientemente. Se hace indispensable realizar un minuciosö trabajo hermenéutico y heurístico de las fuentes documentales disponibles. Una primera aproximación por ejemplo, nos llevaría a constatar que sí bien los hechos de la campaña peruana fueron narrados por individuos pạttićipantes, en la mayoría de los casos éstos pretendieron mantenerse en el nivel narrativo objetivo, puramente descriptivo, eludiendo distinguirse como seres 
reconocibles, soslayando sistemáticamente la descripción de personajes y sus posturas psicológicas. Obviando ser "prolijos", como insistentemente señalan, se escudaron en el pretexto para evitar una postura crítica Procuraron mantener el tono sobrio que caracterizó a la crónica española, negándose a llamar la atención sobre sus acciones y sobre sí mismos, tanto como revelarse orgullosos de sus actos. Prueba de ello sería el desinterés por difundir y preservar dicha gesta que se advierte en la ausencia de crónicas en las bibliotecas peruanas del siglo XVI (Cfr. Hampe, 1996 cit., passim).

También debemos considerar la motivación que subyace en una manifestación artística diferenciadora. En un primer momento el español en el Perú no tuvo razón para sentirse "otro". Él conducía la cultura dominante trasladada desde la metrópoli, por lo tanto -aparte del hecho inestable y comprometido de la conquista mismo- no había una razón apremiante que lo impulsara al mostramiento. Ésta se presentará conforme transcurra el siglo XVI y sobretodo en el siglo XVII, cuando comience a sentir que está construyendo unidades que considerará con derecho a que sus pares en Europa y América reconozcan y validen.

Otro factor que podemos recordar es que el tema religioso era prioritario en la tradición española, por lo que el tema histórico conmemorativo no fue común. A ello se estaría sumando la característica condición cultural de los hombres que llegaron al Perú. La tradición a la que pertenecían, mayoritariamente andaluza, además de estar fuertemente mediatizada por la cultura musulmana anicóngeaPèracfundamentalnenterural campesina, lo que supone condiciones que afectan la relación de las comunidades con la religión en sus creencias y prácticas profundamente enraizadas en la población. Éstas debieron conducir las preferencias iconográficas en los niveles medio de la sociedad en la colonia y aún la de la clase dominante que compartía el mismo orígen. A través del arte funerario, y la promoción del arte devocional institucional, se canalizará el reconocimiento y la aspiración al honor al que, como hombres de su siglo, aspiró la mayoría de los promotores en la tierra para sustentar su dominio.

Consideremos las particularidades de la obra de creación artística en general. La obra de arte presenta varios niveles de significación. El "representacional" referido a su apariencia concreta, y el de su "significación" que puede ser interpretado (Panofsky, El significado de las artes visuales. Buenos Aires, 1970, Cap. I; Gombrich, Ernst. Imágenes simbólicas. Madrid, 
Alianza Editorial, 1983, 13ss). El significado, sin embargo, depende de factores variados según la condición del intérprete. En lo que se refiere a seleccionar temas que cumplieran una intencionalidad determinada, en el Perú del siglo XVI intervinieron variados factores, resaltando entre ellos la condición del comitente y la del eventual espectador. Para dilucidar la intención detrás de cada tema debemos analizar las obras de acuerdo a los registros de los diversos promotores y de los receptores a los que estaban dirigidas, en función de quienes fueron seleccionados los temas:

1. Españoles cultivados, civiles o religiosos con /sin óptima posición económica.

2. Españoles con educación sumaria con / sin recursos económicos

3. Indígenas, entre los que distinguimos dos grupos:

a. los que estaban siendo instruídos:-alta nobleza con poder económico

b. los que debían continuar pasivamente explotados y no eran instruídos

4. Puede ser significativo incluir una división adicional de esclavos y servidores, entre inđigenàs (y hegros, duyo trato con los sectores anteriores podría hacer necesario un sesgo particular en los temas a representar y en las modalidades đe incentivar el culto a las imágenes religiosas cristianas.

Las formas representacionales fueron fundamentales para estos grupos, tanto como las circunstancias en las que eran presentadas. Importante rol cumplió la parafernalia alrededor de las festividades, la que cumplía objetivos de competencia, seducción, compromiso, adulonería y piedad manifiesta, que no pueden obviarse al momento de seleccionar los temas. Cada obra de arte habría que clasificarla según el tipo de los comitentes y de los receptores potenciales antes de analizarla, porque no se trataría de un fenómeno uniforme sino matizado de acuerdo al interés en cada caso. Trataremos de situarnos en la posición más genérica de acuerdo al objetivo expositivo de este trabajo.

Consideraremos algunas de las obras producidas en este período y las fuentes documentales de los cronistas y otros escritos y testimonios del siglo 
XVI, referidos a aquellas manifestaciones artísticas que no han llegado hasta nosotros.Las ocasiones en las que aparece un motivo americano en esta primera etapa lo hace desde una focalización europea particular. Los tres temas que hemos seleccionado los presentaremos en cuanto la importancia ideológica que subyace en el sentido de los mismos, como tendencias que se imponen en la iconografía colonial del siglo XVI con proyecciones a los siglos posteriores. Nos basamos para su análisis tanto en fuentes gráficas como documentales.

\section{El tema clásico: Prevalencia de la cultura europea}

El tema clásico estuvo entre los más frecuentes en el arte efímero así como en los tapices y elementos decorativos que adquiría la nobleza española de talleres flamencos e italianos. No fue de los temas preferidos en la pintura y escultura permanentes, por lo tanto su repertorio fue reducido en comparación al interés que mostraron por él otros países europeos. El tema clásico tuvo propagadores sobretodo entre los personajes vinculados a la corte de Felipe II (Pizarro Gómez, Francisco Javier Arte y espectáculo en los viajes de Felipe II (1542-1592) Madrid, Ediciones Encuentro, 1999, 29). Con frecuencia, y según una antigüa tradición, los temas clásicos aparecieron concordados con aquellos cristianos cuyo mensaje se deseaba reforzar. En esta línea una de las fuentes de la primera mitad del siglo XV fue De Temporibus de Alonso de Madrigal, el Tostad6 y btra, mâs-específica, del mismo autor -que, como dato significativoula chuestroCemäeraparece en una biblioteca cusqueña en 1576 (Hampe, 1996 cit., 89)-: Sobre las diez questiones vulgares propuestas al Tostado e la respuesta e determinación dellas sobre los dioses de los gentiles... Ambas obras permanecieron inéditas hasta que fueron impresas en el siglo XVI a expensas del cardenal Francisco Jiménez de Cisneros, (López Torrijos, Rosa. La mitología en la pintura española del Siglo de Oro. Madrid, Cátedra, 1995, 40-41), activo propulsor de un saber renovado en la época. Estudios recientes han establecido la dependencia con los textos de Madrigal de un tratado de mitología posterior que circuló en España desde 1583, que fuera considerado como modelo de su tipo en lengua castellana, la Philosophia secreta de Juan Pérez de Moya. Esteban Gállego menciona Imagini degli dei delli Antichi de Vicenzo Catari a la que supuso el antecedente inmediato de Moya. La obra de Catari se había publicado en Venecia en 1556 y 1567, sin láminas, las mismas que cuando fueron agregadas en la edición de 1569 se consideraron "extrañas y sugestivas", de "aspecto raro" y 
con "esóterico encanto". Lo sugestivo se refería a que Catari había incluído descripciones de dioses americanos aztecas. Ediciones posteriores en el siglo XVII fueron patrocinadas por la Compañía de Jesús (Ibid., 80), que no pareció impresionarse por las implicancias religiosas de su difusión. La posición favorable a los presupuestos clásicos demostrada por parte de la intelectualidad humanista española también fue canalizada exitosamente a través del asunto pastoril cristianizado, que conocemos tuvo un gran éxito en la poesía castellana (Gállego, Julián. Visión y símbolos en la pintura española del Siglo de Oro. Madrid, Aguilar, 1972, 63, 85). En la opinión que suscitó el escrito de Catari se advierte una cierta apertura frente a lo americano que irrumpía como perturbador de las ideas consagradas sobre el mundo conocido y que se presentaba, además, como un hecho controversial en sus consecuencias pasada la primera mitad del siglo XVI.

En América el interés por la Antigüedad Clásica se condujo de manera similar a como sucedió en la península, tanto por las costumbres de los funcionarios e inmigrantes cultos que llegaron en el siglo XVI, como por el afán emulatorio que caracterizó a la sociedad colonial conforme se fue consolidando. Las obras de tema clásico fueron frecuentes en algunas de las bibliotecas cuyos inventarios se han dado a conocer (Hampe, 1996 cit.) Uno de los temas que formó parte del imaginario ibérico americano que se remite a la tradición clásica, fue el de los "seres extravagantes" que con frecuencia aparecieron en las representaciones vinculadas al mundo nuevo. También estas figuraciones formaban parte de las creeticias populares europeas que se habían mantenido vigéntesceomo parte de Tapexpliçéción del mundo medieval (Pease, Franklin "Temas clásicos en las crónicas peruanas de los siglos XVI y XVII": Hampe, Teodoro (Comp.) La tradición clásica en el Perú virreinal, Lima, Fondo Editorial UNMSM; Sociedad Peruana de Estudios Clásicos., 1999: 17-34; 21) Efectivamente no era exclusivamente la tradición clásica la que se invocaba, aún haciendo referencia a sus autores, tanto como lo que de ella había subsistido por corresponder a la mentalidad de los siglos subsiguientes. Ya en La Edad Media fantástica, Jurges Baltrusàitis (Madrid, Ediciones Cátedra, S.A, 1983) llamó la atención sobre estos fenómenos humanos, o pseudo humanos de diverso tipo, que aparecen profusamente en los manuscritos miniados y que fueron generosamente usados en los primeros libros impresos. La fuente clásica implícita en ellos fue una supervivencia de repertorios antigüos, nunca totalmente abandonados, que alimentaron de manera diversa el sentido de lo maravilloso medieval, enriquecidos con aquellos provenientes del Cercano y Lejano Oriente, y con no poco de la fabulística 
tradicional local, fruto de fuentes no reconocibles actualmente, a las que genéricamente se denomina "no cristianas", sin distinguirlas en sus orígenes. Los siglos XV y XVI asumirán estas representaciones naturalmente, porque habían estado vigentes durante siglos, incluso en la decoración iconográfica de los templos cristianos más ortodoxos. Por otra parte la época clásica no había inventado todo lo que se le atribuía. Las fuentes orientales habían sido motivo de inspiración y adaptación constante, de mutuos préstamos y apropiaciones. Después de todo fue al referirse al mundo parcialmente conocido que surgieron muchas de las elaboraciones que hoy se le adscriben, tal como demuestran las narraciones dejadas por peregrinos a los lugares santos y las de comerciantes con el Oriente. De la misma manera la imaginación indígena americana daba muestras muy cercanas de combinaciones y deformaciones expresivas en su decoración artística, en algunos casos asimilables a las que el español conocía como orientales, lo que resultó, entre otras consideraciones, en la tesis de que los pueblos encontrados pudieron haber tenido tal orígen.

Entre los españoles en el Perú puede localizarse un grupo de seglares que evidenciaba un manejo fluído de la historia clásica. La usaban como sustentatoria de posturas coyunturales que formaban parte de su actividad y responsabilidad política desde los puestos dirigenciales. Por tanto no se trataba de "gente común" (Lohmân, Guillermo: "Huellas renacentistas en la literatura peruana del siglo XVI": Hampe 1999 cit.: 115-127; 116). Franklin Pease mencionó la posibilidad queatrofsector insfruido, como el de los religiosos cronistas, con ongnanejocmáslfactible/de diversas fuentes, tuvieran acceso a textos apócrifos y a decididas falsificaciones de supuestos autores clásicos, según se puede detectar en algunos escritos desde el inicio del siglo XVI (Op. cit., 27ss). Con ello se abre la posibilidad de que los propulsores de obras de arte en la época se valieran de este medio para promover motivos iconográficos orientados a sustentar principios ideológicos, como parte del recurso retórico de la persuación. Cuánto de la iconografía que fue promovida por religiosos y seglares cultos en esta etapa del siglo XVI dependió de estos presupuestos ideológicos y cuánto de ello creyeron sus auspiciadores que sería asimilado por los receptores inmediatos entre la población española común e indígenas, es lo que debe determinarse.

Se afirma que en España la utilización del lenguaje clásico en las construcciones conmemorativas efímeras durante el siglo XVI se convirtió en un recurso portador de un contenido político (Pizarro, Op. cit., 59) y es en este 
sentido que entendemos se practicó en el Perú. El antecedente de esta práctica fue la entrada triunfal de un general vencedor, o la de un gobernante próximo a asumir su cargo, practicada desde la antigüedad. El 15 de mayo de 1544, después de intensas negociaciones conciliadoras, ingresó en Lima el representante real don Blasco Nuñez Vela: "debaxo del Palio, repicando todas las campanas y sonando muchos instrumentos de música; llevándole por medio de los arcos Triunphales que tenían hechos, estando las calles enramadas y entapizadas" (Fernández, Diego "el Palentino". Primera parte de la Historia del Perú. (1571) Lima, edición Manuel de Odriozola, Documentos literarios del Perú, imprenta del estado, 1876, Libro I, Cap. IX) No tenemos información adicional sobre el aspecto iconográfico de los arcos con los que fue recibido el representante de Carlos V, ni tampoco podríamos asegurar que la descrita fue la apariencia exacta de la ceremonia, o si Diego Fernández se limitó a reproducir el tratamiento usual en estos casos, desentendiéndose de una mejor descripción. Agustín de Zárate agrega que quienes acompañaron en su entrada a Blasco Nuñez Vela "vinieron con él hasta la ciudad de los Reyes, donde fue rescibido con gran fiesta, metiêndole debajo de un palio de brocado y llevando los regidores las varas, vestidos con/sus ropas rozagantes de rosa carmesí, forradas de damasco blanco, y le llevaron a la-iglesia y a su posada. (Zárate, Agustín de. Historia del descubrimiento y conquista del Perú y de las guerras y cosas señaladas en ellas acaecidas hasta... (1551) Lima, Biblioteca Peruana, Editores Técnicos Asociados, 1968, T. II, Libro V, Cap. III).

Poco después otra referencia a un intento en este sentido lo encontramos protagonizado por el 'rebelfe Gonzalo Pizarro apoyado por conspícuos representantes eclesiásticos. Cuenta Agustín de Zárate que Gonzalo, creyéndose vencedor y acompañado de un contingente de aproximadamente 200 hombres, llegó a Lima desde Trujillo. El ingreso del caudillo a la ciudad fue motivo de discusión entre su gente: "y en la entrada hubo diversas opiniones sobre las ceremonias con que se haría; porque sus capitanes decían que le habian de salir a rescibir con palio, como a rey, y otros, que más comedidamente lo trataban, aconsejaban que se derrocasen ciertos solares, y se hiciese calle nueva para la entrada, porque quedase memoria de su victoria, de la manera como se hacía a los que triunfaban en Roma. Gonzalo Pizarro siguió en esto el parescer del licenciado Carvajal, como lo hacía en todas las cosas de su importancia, y entró a caballo, llevando sus capitanes delante de sí, a pie y con los caballos de diestro, llevándolo en medio el arzobispo de los Reyes y el obispo del Cuzco y el obispo de Quito y el obispo de Bogotá, que habían venido por la vía de Cartagena a rescebir la consagración al Perú; acompa- 
ñándole asimesmo Lorenzo de Aldana, su teniente, con toque de cabildo de la ciudad y los vecinos della, sin faltar ninguno, teniendo para este acto las calles muy bien aderezadas y enramadas, y repicándose las campanas de la iglesia y monasterios, llevando delante mucha música de trompetas y atabales y menestriles; y con esta solemnidad fue a la iglesia mayor..." (Zárate, Ibid., Libro VI, Cap. V). La alusión al triunfo romano estaba presente en la concepción imaginaria del grupo. Pero no hubo de consolidarse esta posición de mando. Es por ello que Guillermo Lohmann se refiere a lo que considera la primera expresión pública de la cultura clásica en el Perú, a instancias de la entrada de don Pedro la Gasca en Lima, que la ciudad celebró el 17 de setiembre de 1548 con juegos y danzas. Se basa Lohmann en una descripción que también aparece en la crónica de Diego Fernández, en la que fue aludida Troya: "Guanuco y la Chachapoya / te besamos pies y manos/ que por dar al Rey la joya/ despoblamos nuestra Troya/ trayendo a los comarcanos" y otra "Yo soy Piura deseossa/ De servirte con pie llano/ que como Leona raviosa/ me mostré muy animosa/ para dar fin al tyrano" (Ibid., 396, 395) La transmisión de tales fuentes clásicas al Peru en fecha tan temprana, supone Lohmann que pudo darse a través de miembros del séquito del virrey y por libros impresos que llegaron a Lima en los equipajes de los primeros españoles, o que les hubiesen sido enviados desde España. El interés por obras de este tipo parece haber sido sostenido, al punto de permitir el funcionamiento exitoso de librerías distribuidoras especializadas, y la existencia de importantes bibliotecas particulares evidenciada en los inventarios realizados, a los que remitimos para la ampliación def fema (Lohnann, Op. cit., 119ss.; Leonard, Irving. Los libros del "eonqquistador, México, FCE.SQ953; Hampe, 1996, cit.; Núñez, Estuardo: "Henrique Garcés, múltiple hombre del Renacimiento": Hampe, 1999 cit., 129-144). Baste señalar que entre los autores que se mencionan en bibliotecas detectadas entre 1542 y finales del siglo XVI figuran entre otros, Terencio, Justino, Cicerón, Tito Livio, Horacio, Séneca, Apuleyo, Catulo, Plinio, Aristóteles, Marcial, Homero, Virgilio y Petrarca. Guillermo Lohmann deduce que esto "pone de manifiesto la difusión de los programas iconográficos inspirados en los temas procedentes de la Antigüedad, a los que la masa popular no parece haber permanecido indiferente o ajena a su simbología" (Lohmann, Op. cit., 124). Nosotros -menos optimistas- suponemos que los temas seleccionados estaban dirigidos solamente a residentes instruidos, aunque la vistosidad y el colorido, así como la práctica misma del ingreso triunfal, pudo haber comprometido a un amplio sector del público el que, aunque no necesariamente, debió interesarse en su simbolismo. El marco en el que aparecieron las alusiones mencionadas es particularmente signifi- 
cativo de lo que proponemos. Entre las celebraciones se ejecutó "una hermosa danza: tantos danzantes, como pueblos principales avia en el Perú, y cada uno dixo una copla en nombre de su pueblo. Representando lo que en demostración de su fidelidad avia hecho" (Fernández, Diego Op. cit., 395). Además de los mencionados los pueblos representados fueron Lima, Trujillo, Quito, Guamanga, Arequipa, Cusco y Charcas (Loc. cit.), todos recitando coplas demostrativas de las acciones a favor del poder real ante la subversión pizarrista. Si el tema clásico que aparece en estas coplas se difundía principalmente entre los miembros de la corte, otro tanto tuvo que suceder en Lima, considerando el numeroso séquito que acompañaba a las autoridades que llegaban a asumir los más altos cargos administrativos y religiosos. No supone la intervención de pueblos indígenas, pues habría excedido la intención del acto. Hubiese sido ilustrativo conocer también a cargo de quiénes estuvieron las danzas y algunos otros aspectos de su presentación, pero Fernández solamente nos informa que fue una "hermosa danza" (Loc. cit.)

En España solía vincularse alguno de los hechos americanos al esplendor de la Antiguedad Clásica, entre aquellos do sus pensadores e historiadores que creyeron encontrar el paralelo formal entre el mundo encontrado y aquél que habían imaginado como utópico. Aunque se menciona que existían en Lima personajes con suficiente información sobre los textos clásicos como para haber podido sustentar este programa, también es cierto que quienes más y mejor educación habiañ recibido al respecto eran los religiosos, por la misma condición de su ministerio El 6 de enero de 1590 tomó posesión el nuevo virrey del Perú, don García Hurtado de Mendoza y Manrique, IV marqués de Cañete. Para recibirlo se preparó un arco de triunfo en Lima. Quedó encargado de disponer lo relativo a la traza del arco de recibimientó Don Pedro de Santillán, quien encomendó la obra al padre agustino fray Mateo de León: "teólogo y predicador, persona de muy dichoso intelecto y generalísimo en toda suerte de antiguedad y curiosidad, y de admirable traza de ingenio, cuyo parecer se dió muy bien a entender y sentir en el modo de las figuras, casándolas con la ocasión, que es el mayor primor de los significados, porque todos igualasen el deseo de la ciudad y calle por do había de ser la entrada. El era blanco y de razonable altura y con pasamentos. La anchura era lo que decía de cerca á cerca, quedando la puesta vistosa y espaciosa, aunque faltó lugar para poner letras y figuras que algunas personas estudiosas tenían trazadas para el efecto" (Torres de Mendoza, Luis (Dir.) Colección de documentos inéditos relativos al descubrimiento, conquista y colonización de las posesiones españolas en América y Oceanía, sacados en 
su mayor parte del Real Archivo de Indias. Madrid, Imprenta de Frías y compañía, 1867, T. 8, cap. XV; Lohmann, cit.) Hurtado de Mendoza arribó con un numeroso séquito del que formaba parte un grupo de músicos, demostración del cultivo de las artes que caracterizó a miembros de su familia. El ingreso fue pomposo: "arrojándose al pueblo un crecido número de monedas de plata” (Mendiburu, Manuel de. Diccionario histórico-biográfico del Perú. Lima, Imprenta Gil, 1933, 303) El virrey, a caballo y bajo palio, estuvo presidido por un séquito de "indios ricamente ataviados", luego de los cuales continuaban el desfile la guardia de arcabuceros, los gentiles hombres de la casa del virrey, los miembros de la Universidad de San Marcos, los de la Audiencia y otros funcionarios (Loc. cit.,) En la descripción del arco se consigna que: "En lo alto de la cimbra del arco, por timbre, estaban las armas del Rey nuestro Señor ... De un lado y otro destas armas, estaban las de la cibdad, que son una estrella en lo alto, y las tres coronas de los reyes magos, en campo azul. Por orla tenía su mote antiguo que dice así 'Hoc signum veré Regum est' ... A estos escudos respondían más abajo unos escasamentos cavados en la pared del arco do estaban dos figuras pintadas, la una a la mano derecha, la otra a la izquierda" (Documentos, cit.) señala Lohmann que ambas "de pincel". La de la derecha era un viejo venerable vestido como rey indio sentado debajo de un árbol. Representaba "el Reyno del Perú". El correspondiente mote latino rezaba: sub umbra illius quem desideravam sedeo. El árbol estaba ceñido por una parra, significándose el matrimonio del virrey -era el primero que ascendía al solio de los representantes del monarca en el Perú que llegaba acompañado de su consorte-Qy para dat $\mathrm{G}$ entender que la compañía no le habría de sergincőmodanpara Gegir el spaís, antes bien ayuda y soporte. La correspondiente leyenda expresaba lacónicamente: mutuum auxilium.. Del árbol colgaban las armas del virrey -Hurtado de Mendoza- y de su cónyuge -Castro- "incorporadas en un escudo y las de la ciudad en el suyo" (Documentos, cit)... En el lado opuesto se diseñó una doncella con una balanza en las manos, imagen de la justicia. Empuñaba unas riendas asidas a un fresno ("freno" en Documentos cit.) (para denotar prudencia): una de ellas tirante, y la otra laxa. La leyenda estaba inspirada en el verso de Virgilio (con una ligera variante): et premere laxas sciret dare jusos habenas. En la balanza uno de los platillos lucía los instrumentos propios de la Justicia (grillos, cadenas y espadas) (Lohmann, cit) y el otro de los signos de misericordia y premio, ramas de oliva, palmas y estaba más inclinado (Documentos. cit) ... En la otra mano la imagen sostenía un ramillete de flores y frutos en sazón ("frutas sazonadas" Loc. cit.,) ostentando como signo fructus justitiae in tempore. 
El vano del arco se cerraba ("en dos puertas" Loc. cit.).).En la primera de las hojas aparecía pintado un capitán general con una lanza en la mano izquierda; con la mano derecha ayudaba a levantarse a una mujer postrada a sus pies -significando la ciudad de Lima- ("vestida realmente con coronas y estrellas y a sus pies muchos edificios arruinados ' porque la levantaría de su polvo y caída" Loc. cit.) (evocando su denominación oficial de Los Reyes) Entre ambas figuras se divisaba el mausoleo del primer gobernante que llevara el título de marqués de Cañete con ejercicio del poder en el Perú (1556-1560) ... En la otra hoja de la puerta se había pintado a Eneas, portando sobre sus hombros a su padre, Anquises ... Eneas representaba a don García que vadeaba unas aguas con una espada como báculo... Para dar a entender que había regresado al Perú al amparo de la virtud que adornara a su padre se pintó a sus pies un cervato ("cervatillo" Loc. cit.) (rumiante del que la leyenda decía que en medio de las aguas vuelve ("el hocico a la tierra" Loc. cit.), porque la huele desde muy lejos) ... En la parte superior de la puerta se pintaron el sol y la luna ; el primero estaba rodeado de nubolocidad ("nublados" Loc. cit.), mas él muy resplandeciente y claro ...; por su parte la luna representaba la ciudad de Lima, y aparecía en plenilunio y serena ..." (Lohmann, Ibid., 125-126) Encima del arco estaba la dedicatoria al virrey "Señalado y pueblo de Lima ofrece este arco al Señor García de Mendoza por la esperanza que tiene que con su venida sea reparada esta ciudad" (Documentos, cit.).

Tal como estan descritas, estas figuras recurrian a la relación analógica, además de estar acompanadas por emblemas ${ }^{y}$ reyendas que conducían al observador cultivado a interpretar en el sentido correcto la composición, de acuerdo a la intencionalidad de los comitentes. En éstos y otros casos consignados en los que se levantaron túmulos y arcos de bienvenida, necesariamente debemos restringir el efecto total de las elaboraciones a un sector definido de receptores. Fundamentalmente fueron construcciones elaboradas para informar sutílmente al virrey sobre asuntos de interés político administrativo que pudieran, o no, comprometer a la población limeña del siglo XVI en general. Siendo así, los inteligentes en los detalles de los mismos, en especial los religiosos, debieron impartir explicaciones en cuanto les fueran solicitadas, o lo consideraran pertinente. De manera que la lectura, tanto como la información contenida en estas construcciones llegaba a los no instruídos a través del sentido que, los que sí lo eran, querían $\multimap$ podían- darle. Debió restringirse su concepción al sector español sobretodo si consideramos que no se aplicaba a estos programas elemento alguno que se refiriera directamente 
a la realidad indígena de la tierra. La toma del Imperio rápidamente supuso su disolución formal en las representaciones auspiciadas por los españoles. Lima aparecía como una figura femenina postrada en posición de recibir merced la que, vinculada a los edificios ruinosos y al texto que acompaña a la representación, nos remite al terremoto del 9 de julio de 1586 que ocurrió durante el mandato del virrey Fernando Torres de Portugal, conde del Villar. El sismo fue debastador, con lo que la actitud de la mujer se relaciona directamente con la aspiración de que el nuevo virrey reedificara la ciudad. Con mayor razón cuando asociamos esta imagen con su equivalente analógico en la otra hoja de la puerta.

No es el mismo caso el de la figura del Inca que se agrega a la composición. Está representada por un anciano sentado que se muestra inactivo, protegido bajo la sombra del poder monárquico que se renovaba en esa ocasión. El ciclo del Imperio había terminado, se remarca su desaparición. El mote latino lo confirma al referirse a su sumisión pasiva al estado español. Un elemento contrastante con esta deslucida representación lo constituye el grupo de indios ricamente ataviados que presidió el cortejo virreinal. Aunque lo advertimos igualmente subordinado, tanto por la posición que ocupan en el grupo, como porque deducimos que estaban cubiertos con atuendos occidentales, tal como correspondia a su limitada condición de criados. Los indios aquí son presentados como elementos-en coherencia con la comitiva de recepción. Por otra parte presidían el cortejo como lo habrían hecho con el mismo Inca, superponiendo asî ta concretización del poder español a la remebranza de la cóneretizaciónf Inea, una dercuyas realizaciones nos ha llegado a través de las crónicas iniciales sobre el ingreso de Atahualpa en la plaza de Cajamarca. Mateo de León parece haber propuesto la imagen reciente asociándola a la anterior, anulando visual y conceptualmente la nativa.

Encontramos una referencia significativa respecto a la posible vinculación de los indígenas al imaginario de la cultura clásica europea, la misma que estaba presente con cada vez mayor frecuencia en la temática plástica no religiosa. Se menciona que en 1570 la Iglesia de Quito prohibió "la venta de imágenes profanas a los indios" (Franco, Jean.”La cultura hispanoamericana en la época colonial" En: Iñigo Madrigal, Luis (comp.). Historia de la literatura hispanoamericana. T. I. Madrid, Cátedra, 1982 (35-53) 43) Habría que determinar a cuáles imágenes profanas se refería el decreto y, en todo caso, indagar las razones por las que existían mercaderes que las consideraban productos comercializables y, más sorprendente aún, que estas imágenes 
pudieran ser una atractiva adquisición para los indígenas, en el supuesto que estaba fuera de su comprensión el simbolismo que contenían, considerando que habían transcurrido menos de cuarenta años del arribo español. El hecho mismo de haberse emitido una disposición nos indica que la actividad estaba difundida entre los pueblos de indios y que, además, representaba un problema que debió encararse. Por otra parte nos remite al valor particular y no dogmático que los nativos otorgaban a las imágenes, cualquiera fuera su procedencia.

\section{Tema 2: La filiación: en defensa del padre}

Un tema en el que se insiste en las representaciones plásticas y no plásticas del siglo XVI, es el de la filiación a los personajes sagrados. Vicente de Valverde repitió al Inca Atahualpa el requerimiento en el que se señalaba expresamente la creación única de la humanidad por el dios cristiano. Atahualpa cuestionó tal filiación porque a su vez reconocía otra, que le era ancestral y la que, por otra parte, sustentaba el póder por el cual se encontraba en tal circunstancia. No era diferente la preocupación de Valverde por hacerle comprensible su punto de vista. Aceptar que los hombres habían sido creados por su dios también sustentaba el orden monárquico que lo enviaba y el aparato por el cual Francisco Pizarro le había encargado respaldar la empresa que, precisamente, en ese momento defendía Podríamos a firmar que desde entonces se estableció la controversia del padre que enfrentará a ambas culturas y que hasta hoy puede "identificarse en la dificultad de" integración del pueblo peruano: la defensa del clan.

Cuando se propiciaron las pinturas de árboles genealógicos en los que se llegaban a hermanar Incas y monarquías europeas bajo un único orígen, la intencionalidad variaba entre lo afectivo y lo subliminal. Conjugar ambos sistemas implicaba absorber la genealogización andina y disolverla, diluirla en la europea. Aparecía el conjunto como una suerte de Incas consecuentes que avalaban frente a su pueblo una línea de ascendencia supeditada a la extranjera lo que, por ende, resultaba en convertir su propia ascendencia en inconsistente y vacía. Junto con esta aceptación desaparecía la religión que se sustentaba en las creencias fundacionales, que le eran específicas y que había mantenido la estructura del Imperio. El mismo sentido, aparte del evidentemente político, tuvo el apoyo que, desde Vicente de Valverde y otros funcionarios, se dió al establecimiento de alianzas y vínculos sanguíneos de 
españoles con la nobleza Inca. En este contexto se inscriben los temas del Cristo crucificado y el Padre Eterno en su relación al Hijo sufriente y sacrificado por la redención, así como el tema trinitario. No olvidemos que el soporte intrínseco de estos temas es que el Padre ofreció al Hijo, se desprendió de él y lo entregó a la inmolación en favor de su creación humana, perdida por haber abandonado sus preceptos en el pecado. Su posterior resurrección y ascenso al cielo suponía su triunfo en la Gloria, en un espacio supraterrenal que lo reinvindicaba y transformaba en "otro". In separaba del género humano del cual había sido temporalmente parte.

La genealogización extrema y particular puede advertirse igualmente en un aspecto de las circunstancias de los religiosos españoles en esta época. Las crónicas informan sobre la actitud de algunos religiosos quienes ejercían su ministerio en lugares apartados, aislados de otros de su condición y que de esta manera cumplieron su labor manteniendo un escaso, aunque frecuentemente nulo, contacto con los españoles. De la misma manera conocemos de religiosos que guardaban este mismo recogimiento al interior de los complejos monásticos. Por esta práctica la religión se estableció como una forma de conciencia particular de quienes la abrazaban -en la que se advierte la influencia del pensamiento de Erasmo de Rotterdam- como también condujo a la aparición de tendencias mesiánicas, en las que la salvación eterna a la que se aspiraba pasaba por una autoconciencia de la diferencia y, con ello, por una defensa de la filiación exclusiva. Desde la Edad Media esta actitud en ocasiones encubría una religiosidad distinta, no mánipulable, que se manifestaba con formas nuevás, liberadofas, a las que se rechazaba por considerarlas inauténticas. En esta época el pensamiento erasmista impulsaba la corriente, extendida entre los miembros de la Iglesia, que buscaba establecer una relación personal con Dios, ajena a lo colectivo y ritual demostrativo.

Otra forma de individualización, pero a partir del grupo nativo, se produjo en la apropiación de la apariencia externa de las figuras divinas de la religión cristiana con la aplicación de elementos autóctonos a sus formas expresivas. La comunidad indígena fue consecuente con el aspecto formal del nuevo dogma, pero dotándolo de elementos reconocibles de su cultura. En este caso las imágenes se incorporaron a la propia filiación, se personalizaron. Las diversas advocaciones de la Virgen María y de los Cristos se pueden considerar en este marco. La filiación con el padre queda subyacente en la actitud de españoles e indígenas defendida de la agresión externa, cualquiera 
fuera su procedencia. Aceptando en este hecho lo que implica de reconocimiento personal, debemos estar atentos a identificar la participación por sugestión de los religiosos, en el aspecto de las imágenes devocionales indígenas. El religioso estaba en la posibilidad de inducir a los indígenas para que adoptaran una representación por medio de una asociación formal obvia -como el caso Virgen / cerro- que encubriera una identificación a la inversa. En este caso por ejemplo sería la Virgen la que podría haber adoptado la apariencia del cerro desde la manipulación de la focalización hispana y no ser una respuesta apropiativa desde la visión indígena, para la que no debió ser condición indispensable valerse de este subterfugio para aceptar su culto, toda vez que la apariencia no se muestra como factor determinante en su religión. Particularmente en la Virgen de Copacabana el cerro convocado es el de Potosí (Gisbert, Teresa. Iconografía y mitos indígenas en el Arte, La Paz, Gisbert y Cía., 1980, 17ss.) fuente de inagotables riquezas para los españoles y destrucción para los indios, a quienes por esta apropiación formal pudo justificárseles el sacrificio. Franklin Pease formuló esta identificación como resultado de un proceso sincrético derivado de la incomprensión, por parte de los españoles, del concepto de la divinidad del mundo subterráneo prehispánico. Esto resultó en que lo descuidaran y así permitieron que permaneciera como "un espacio indiscutiblemente andino... y en consecuencia fue más fácil su rápida identificación -sincréfica, no sintética- con la Virgen María" ("La cultura en el Perú en los tiempos de la evangelización" Revista Peruana de Historia Eclesiástica $\mathrm{N}^{\circ}$ 3. Cusco. IPHE. 1994 (207-218, 211-212). Pero igualmente fue la zona reservada a la permanencia y reconstrucción del reino del Inca. De lo que se deduce que por este procesós sè termina identificando con el rey español y, más ampliamente, con Cristo. Podríamos sugerir que esta posible identificación despoja a la representación impuesta de su contenido, para sumirla en otro que se advierte en sus modificaciones formales. Ya no es lo que era, pero no por una comprobación evidente, sino por la manera como es recepcionada por un sector de espectadores que aceptaron convencionalismos válidos exclusivamente para ellos. Una Virgen "mestiza" presenta una apariencia que no significa lo mismo para todo espectador porque incluye sutilezas conceptuales propias de un lenguaje simbólico que no es compartido, sino es resultado de una adaptación para un grupo específico de observadores. Por eso muchas veces no interesó la lengua en la que se predicaba porque, finalmente, era un hecho irrelevante lo que se manifestara con ella. De la misma manera tampoco sería significativa la imagen en sí misma. 
El vestido diferenció al hombre del animal desde hace lejanos $50 \mathrm{mil}$ años, o más. Motivado por la necesidad, el uso de cubrir el cuerpo se transformó con los siglos en distintivo de los individuos y su circunstancia de acuerdo a la calidad, elaboración y color del vestido. En los mitos primitivos el traje es presentado como premio de los dioses a quienes los sirven, así como se despoja de él a quien comete infracciones que ofenden los designios divinos y comprometen el bienestar de la comunidad. El destierro y el desnudo suelen presentarse asociados como penas máximas de castigo. Quitar el traje es cuestionar la condición humana de un individuo y condenarlo al ostracismo.

Desde el medioevo, y como resultado de la concepción cristiana, el cuerpo fue objeto de especial celo. Revelador de la inocencia ancestral fue convirtiéndose, a causa del pecado original, en fuente de todo suplicio y oprobio. El cuerpo desnudo durante el Medioevo pasó por varios estadios en los que casi siempre estaba involucrada la vergüenza, ya fuera por sus implicancias sexuales, de carencia o de castigo. En muchas culturas del mundo el cuerpo desnudo implicaba pérdida de la privacidad que sustentaba la humanidad del individuo y de los signos distintivos de su posición social, equivalía a una degradación.

Pero también, y en cierto modo vinculado a ello, se otorgaba otro valor simbólico a la desnudez: Sul extrấeza y âsociada ẩ ella encontramos al "salvaje". Cuando llegaron ar Eeropactais phimeras muestras visuales de los indígenas americanos, se les representó desnudos. En el escudo que Fernando el Católico entregó en 1508 a don Diego Méndez de Segura, Escribano mayor de la armada de Cristóbal Colón en su último viaje se representó "las islas y la canoa y dos indios desnudos aislados a los lados, cada uno con un bastón dorado en la mano" (Bataillon, Marcel. Erasmo y España. México, Fondo de Cultura Económica, 1982, 808, nota 7), en referencia a una acción arriegada que protagonizó. Otro ejemplo recurrente aparece en los aguafuertes en los que aparece Cristóbal Colón en la isla La Española realizados por P.B. Bouttats para la edición de las Décadas de Antonio de Herrera en 1728. En algunos los americanos son dibujados desnudos y con plumas, a pesar del evidente aspecto occidental de sus rasgos físicos.

Una interpretación al tema del "salvaje" puede darse considerando el contexto de los españoles que llegaron a América, a partir de la necesidad de 
evasión de un mundo hostil y degradante que cundió en la España del siglo XVI, fenómeno que propició el desarrollo de ciertos temas exóticos. La decisión de los hombres que emprendieron el viaje de exploración a fines del siglo XV y primeras décadas del XVI, pudo haberse sustentado en la necesidad de huir de un mundo percibido como apartado de la gracia divina. En el caso peruano el insistente apoyo divino que convocan los cronistas para con la campaña, los convertía en seres privilegiados, escogidos para luchar contra las fuerzas malignas del demonio que parecía haberse enseñoreado en el mundo que conocían. Los seres monstruosos que aparecen en los textos y lo maravilloso de las tierras encontradas brindaban sustento a la necesidad de confianza que les era indispensable para continuar las exploraciones y justificar sus acciones. Fue indicio del favor celestial la facilidad de las conquistas, así como la amplitud y fecundidad de los territorios. La tendencia a lo maravilloso y exótico se ve plenamente traducido en las excepcionales cualidades que advierten en las tierras y que ellos exageran, aceptando las más descabelladas explicaciones. La imagen que transmiten es la del caballero conduciéndose en un mundo ideal, paradisíaco y que en gran parte se alude como deshabitado, en tanto no lo estaba de seres afines. En este contexto el "buen salvaje" encaja, magnifica y sustenta la narración, permaneciendo como tema en la representación plástica. En términos generales el tema del desnudo aparece con relativa frecuencia y fue en cierto modo popular en España, hasta que las disposiciones del Concilio de Trento, seguidas por los provinciales correspondientes, emprendieron campañas disuasivas respecto a las jmágenes consideradas como "indecentes".

"Jorge Puccinelli Converso»

La desnudez plástica del habitante americano implicó en algunas ocasiones su intrínseca inocencia, pero no podía desligarse la imagen a la que resultaba de considerar la falta de protección del cuerpo como un signo de ostracismo, lo que implicaba separar a los individuos inadecuados o no integrados, de los grupos sociales cuyas normas habían transgredido. Desnudo permanecerá en las alegorías del hombre y del continente, connotativas del salvaje. Estas imágenes del "buen salvaje", pero salvaje al fin y al cabo, transmitían varios mensajes. Su marginalidad y conducción a la esclavitud se justificaban plenamente por ser elementos perturbadores del orden. Su falta de vestido los delataba. Vivían alejados del orden divino y debían ser incorporados al sistema, pero desde su condición primera, sin superar su inferioridad y medianía. En cierta forma el publicitar el bautismo de los señores Incas tenía que ver con su incorporación a la sociedad de la que asumían el vestuario y los atributos, tan ajenos a su tradición como eficaces para señalar 
su abandono. En el arco erigido con ocasión del ingreso en Lima del virrey García Hurtado de Mendoza, el viejo que representa al Perú lo hace caracterizado de Inca, con lo que puede interpretarse como representante de un mundo "otro", que no compromete al español El viejo fue "íntegramente" indio y no obstante era representativo del Perú -no hay equivalente formal con otra caracterización de Perú- por lo que podemos entender que los españoles no se consideraban integrados con el país. Escuché el sermón de un oficiante español en la catedral de Sevilla con ocasión de la conmemoración del 12 de octubre, en el que no dudó en continuar -500 años despuésrecreando imágenes de salvajismo y selva virgen en Iberoamérica, rescatadas por piadosos defensores de la fe y portadores de una única forma cultural, no solamente referidos a 1492 sino extendiéndolo a la participación económica, que él consideraba "ayuda", española contemporánea en el continente. La dificultad para comprender el verdadero valor de las culturas americanas se gestó en el primer momento y cientos de años después algunos sectores no han podido superarlo.

La representación del salvaje, sin embargo, apuntaba también a otro objetivo. La desnudez en el Cristianismo connota la inocencia y pureza antes de sucumbir al pecado, que conlleva vergüenza y deshonra. En estos márgenes fluctuará la figura desnuda de acuerdo al contexto visual en el que se le presente y al mensaje que se intente transmitir. Adán y Eva, en un Paraíso americanizado, serían las almas puras no redentas del indígena previo a su descubrimiento. Su dolor después del pecado representaría a los mismos luego de que, implantadore Cristianisho, fueron Eonscientes de sus infracciones a la ley divina. El Cristo martirizado y vejado se presentaba como la mayor culpa. Su sacrificio se insistió que fue en beneficio del pecador, que por entonces parecía ser sólo el indio. Los Cristos sangrantes tuvieron amplia difusión y aparente aceptación en las comunidades indigenas. Con Él su Madre, herida por las flechas del sufrimiento permanente, aparentemente por la convicción que podía generar en ellas la profundidad de la afrenta a Dios en la que habían incurrido con sus prácticas religiosas. Los españoles estaban convencidos de la culpa, y por ello también de la inferioridad, de la raza indígena. El médico filósofo Francisco Sánchez en su Quod nihil scitur (Que nada sabe) (Lyon,1581) incluye: "Y en las Indias, ¿cuánta ignorancia no reinó hasta hoy? Ya, ahora hácense poco a poco más religiosos, más agudos, más doctos que nosotros mismos" (Pedro, de. Op. cit., 70) con lo que aunque reconocía el grado de competencia alcanzado hacia fines del XVI, tomaba como única medida de referencia la instrucción religiosa.

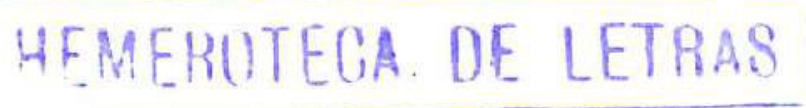


Un texto inédito hasta 1868 que nos parece especialmente significativo acerca de la postura ideológica del español promedio respecto a los pueblos alejados de experiencia es el Viaje a Turquía, el mismo que Manuel Serrano y Sanz atribuye a Cristóbal Villalón (Viaje a Turquía. En: Serrano y Sanz, Manuel Autobiografias y memorias. Madrid, BAE, № 2 (1-149) y Marcel Bataillon al doctor Andrés Laguna (Bataillon, Op. cit., 669) Es el relato de Pedro de Urdemalas, un español de familia acomodada, que narra a Mátalas Callando y Juan de Voto a Dios, dos amigos clérigos ávidos de escucharlo, las peripecias que le sucedieron en un viaje a Turquía entre 1552 y 1556. Vinculado al viaje describe todo lo que le impresionó de la cultura musulmana y de otros lugares europeos. Precisamente a la descripción de Nápoles, uno de los oyentes hace el siguiente comentario: "En fin, acá todos somos bestias, y en todas las habilidades nos exceden todas las naciones extranjeras; ; Dadme por amor de mi, en España toda quan grande es, una cosa tan bien ordenada" (Viaje, cit., 91) Más adelante, conforme se maravillan los amigos con las historias de Pedro referidas a los países musulmanes, Juan de Vota a Dios hace una petición: "Una merced os pido, y es que, pues no os va nada en ello, que no me digáis otra cosa sino la verdad; porque no puedo creer que siendo tan bárbaros, tengan algunas cosas que parezcan llevar camino..." (Ibid., 109) Posteriormente Mátalas Callando añadirá: "Y a propósito, ¿esa jente llamais bárbara? Nosotros lo somos más en tenerlos por tales” (Ibid., 115) El término bárbaro aquí se refiere a "no cristiano", el mismo sentido que encontramos en las narraciones del siglo XVI sobre América, añadidas a las connotaciones aplicables al salvaje. Lo interesante del Viaje es que supone un lento convencimiento, no sin reticencias, del cofibcimiento fraccionado y prejuicioso que los amigos españoles tenían de pueblos que, finalmente, consienten en admirar. Manuel Fernández Álvarez a propósito de este texto, hace un análisis que nos parece interesante reproducir porque su sentido, es aplicable al caso que tratamos:

De esta forma, para los hombres del Quinientos un viaje a Turquía era tanto como asomarse a un mundo prohibido y excitante, del que se sabían pocas cosas ciertas, aunque se decían muchas imaginadas; un mundo que de entrada se tildaba de abominable y maldito, pero que se alzaba formidable, desafiando las iras del cristiano. Era como un reto a la imaginación de los europeos, ya que quien tenía religión, política y costumbres tan distintas, sin embargo había logrado un poder formidable. ¿Es que algo fallaba en los cristianos? ¿O sería que aquel mundo maldito no era tan perverso? Pues 
la razón quería que si se mostraba tan poderoso, algo había de tener de bueno, y aún de digno de copiarse (Fernández Álvarez, Manuel. La sociedad española en el Siglo de Oro Madrid, Gredos, 1989, 490).

La percepción del tema americano en las crónicas de la conquista advierte de una causalidad que bien podríamos transcribir con la de Fernández para el caso turco. Existía una actitud preconcebida en los observadores españoles para todo aquello que no los involucrara directamente, como antes hemos señalado. Puede ser parte de la intolerancia y sin razón que Vives y otros pensadores de su tiempo advertían en su sociedad, por la situación de estancamiento y con pocas posibilidades de progreso que parecía sumirla. En el arco triunfal que se levantó en la Puerta del Sol en Madrid para recibimiento que se hizo a Felipe II en 1570 fue incluida, por primera vez, y a casi un siglo de su descubrimiento, la alegoría de América para acompañar a las tradicionales de Europa, Asia y Africa (Pizarro, Op. cit., 102) Posiblemente parte de la negación hasta entonces del tema americano, o la insistente terquedad en mostrarlo solamente a través de sus representantes más atrasados, evadiendo sistemáticamente reconocer el alto grado de desarrollo de las culturas que encontraron en los nuevos territorios, sobretodo en el Perú y en México, se explica por el angustiado comentario "porque no puedo creer que siendo tan bárbaros, tengan algunas cosas que parezcan llevar camino..." que citamos más arriba, ¿Cómo podía admitir un individuo que justificaba los mayores excesos con el pretexto de la salvación por la fe cristiana que un pueblo que la ignorára pafecierachoehabep lekeontràdo obstáculo para un óptimo desarrollo? Lo poco significativo que fue para España el tema americano se vincula particularmente a los aspectos del "buen salvaje" con "traje de indio", esto es semidesnudo y con plumas. Esta primera percepción del hombre americano quedó grabada permanentemente en el imaginario europeo. Una última anotación literaria puede brindarnos información de la captación que del asunto tenían en España ciertos sectores con experiencia americana. En el auto sacramental las Cortes de la muerte (publicada el 15 de octubre de 1557), de Micael de Caravajal y Luis Hurtado de Toledo aparece un indio que presenta queja frente a los abusos cometidos por los españoles. Caravajal se supone que estuvo con los padres dominicos en Santo Domingo alrededor de 1510 y por tanto tenía la experiencia americana y conocía las circunstancias que condujeron al pensamiento lascasiano. Incluso se hace notar la similitud de su propuesta con las de fray Antón de Montesinos, inspirador de fray Bartolomé de las Casas. Montesinos hizo cerrada defensa 
de los indios en Centroamérica frente a los abusos españoles, en un sermón del 30 de noviembre de 1511 en el convento dominico de la capital de la isla La Española y de Las Antillas, en el que se establecieron las posiciones a favor del derecho indiano (Pedro, de. Op. cit., 47-48). En las Cortes de la muerte el indígena se presenta agradecido por la evangelización pero, asimismo, deja expuesta la contradicción que otros indígenas en su circunstancia ya habían advertido: $Y$ era que "... cuando a los dioses mudos, / bestiales, falsos y rudos/ adorábamos sin ser, / ninguno nos perturbaba de cuantos en nuestra tierra/ ha pasado ni pasaba/ ni hacía crudas guerras..." Con los españoles, llevados a los extremos por la codicia del oro, a pesar de predicar que respondían a los preceptos de un dios misericordioso y justo: "parece que desafueros, / homicidios, fuegos, brasas, / casos atroces y fieros, / por estos negros dineros / nos llueven en nuestras casas ...". El indio ofrece un trato. Que se lleven todo, pero que los dejen vivir en paz (Ibid., 49-50). Este auto presenta una situación al dominio público y refleja el convencimiento de un sector de la población española con experiencia americana. Define una supuesta autocrítica del indígena americano que no soslaya la responsabilidad que supuso la administración española. Advettimos, sin embargo, que en la percepción española quedó relegada la imagen del Perú a la riqueza que se advierte en las Cortes. Dos ejemplos en el Viaje a Turquía informan de ello: "nos vimos con tres mill escudos (de limosna) de fabrica para los ospitales, y restitución de vnos indianos o peruleros ..."; referido a quienes estuvieron en América, y el otro, mâs êspecífico: “ “dicen que es del Duque, lo cual le renta vn Perú" (Viaje, cit. 12 100) 1 inelli Converso"

El significado del vestido se relega así al asunto de la barbarie, pero no debemos olvidar que funciona como signo de identificación étnica, cultural, social y política indiscutible en la historia de los pueblos. En las ocasiones en las que aparecen representados figurativamente grupos compactos en ceremonias urbanas, el vestido es determinante para identificar los niveles sociales y sus diferencias étnicas. En las fiestas prehispánicas los indígenas desfilaban con vestuario de diferente calidad, color y vistosidad de acuerdo a lo que describen los cronistas en las ceremonias de los pueblos andinos: "En lo que traen en la cabeza se conocen y diferencian cada uno de la tierra donde es" (Ruiz de Arce, Juan. Advertencias que hizo el fundador del vínculo y mayorazgo. Lima, Biblioteca Peruana I, 1968, 433) A lo que añade Cieza de León "Y hoy día, donde vemos junta de gente, luego decimos éstos son de tal parte y éstos de tal parte; que por esto, como digo, eran unos de otros conocidos" (Cieza de León, Pedro. Señorío de los Incas. Lima, Instituto de 
Estudios Peruanos, 1967. Cap. XXIII) Las procesiones coloniales, especialmente las del tiempo inicial, tuvieron que mostrar a los grupos indígenas que conformaban la joven sociedad virreinal, desfilando con sus cofradías con sus mejores galas y adornos distintivos, tal como los cronistas describen que era costumbre en sus ceremonias. El vestuario y los estandartes conferían a cada cual su lugar en la multitud, cuanto más si avanzado el siglo XVI sabemos que se detectaba la presencia recurrente y soterrada de prácticas nativas en las festividades cristianas. Paralelamente aparecieron los préstamos y transmisiones de detalles del vestido español, como las mangas, cuellos, chalecos y chaquetillas, pantalonetas, medias y zapatos, especialmente entre los indígenas que, como los "indios ricamente ataviados" (Mendiburu, Op. cit., 303) que acompañaron en 1559 el ingreso del marqués de Cañete, ocupaban lugares destacados. Por las normativas conocemos que la apariencia elegante y rica que muchos adquirieron motivaron disposiciones expresas para prohibir sobrepasaran los límites impuestos por la administración como adecuados. Existen leyes emitidas tempranamente por las que se prohibía a los indios y negros lucir atuendos que por sus características fueron considerados más acordes para un señor que para ellos. Mucho menos se les permitía llevar armas, precausión que suponía más que una conveniencia social. Los colores también se restringían toda vez que variaban en calidad y valor según los componentes de los tintes y la calidad de los importados respecto a los trabajados en la tierra. La mismá objeción se aplicaba a las joyas y adornos, fueran o no de calidad y sólo por su engañosa apariencia. En las representaciones plásticas apareeen estos grupos de acuerdo- sus respectivas convenciones. El mensaje era clafo a quienhlolbbserväral No se permitía transgredir el orden establecido así perennizado. En el segundo Concilio Limense (1567) se prohibieron muchas de las costumbres distintivas de los pueblos prehispánicos. Entre ellos la deformación craneana (cap. 100), los tocados realizados con cabello o el trasquilado (cap. 101), el uso de orejeras y trepanarse los lóbulos (cap. 103), con lo cual se pretendió frenar el encubrimiento de la religiosidad tradicional. Con ello además, se proscribió una práctica que en el siglo XVI estuvo extendida entre gran parte de la población indígena, como medio para preservar los signos culturales que la distinguían de los europeos.

Los tres temas que hemos seleccionado del arte colonial son representativos de la actitud que primó en el primer encuentro cultural entre España y el Perú. Fundamentalmente comprometieron la vida de toda la población aunque no en la misma medida, y abarcaron los variados aspectos de la mentalidad colonial. Se encuentran implícitos y en el sustrato de la sociedad 
y la cultura virreinales que lentamente iba tomando forma en el siglo XVI y que sería plasmada en el arte que propiciaron los diversos grupos involucrados. De un modo u otro, la manera de enfrentar estos temas extenderá su influencia hasta contaminar la imagen europea de América, difundida en su arte y en el arte que se configuró en el nuevo continente, atrapando en su formalismo la conciencia de sus habitantes.

\section{BIBLIOGRAFÍA}

BALTRUSÀTIS, Jurges

1983

La Edad Media fantástica. Madrid, Ediciones Cátedra, S.A.

BARRIGA TELLO, Martha

1992

"Relación entre Iglesia y Arte durante el Virreinato del Perú". Letras, Facultad de Letras y Ciencias Humanas, UNMSM, № 91, 49-63. Lima.

1994

"Los religiosos y el arté en el Perú del siglo XVI". Sequilao $N^{\circ} 7,19-32$, Lima.

1997 "La Iglesia como promotora del legado artístico virreinal". Letras, Facultad de Letras y Ciencias Humanas UNMSM, $\mathrm{N}^{2}$ 94, 3-24. Lima.

(En prensa) "Visiones plásticas encōntradas: España y Perú siglo XVI". Universidad de Friburgo (Suiza). "Jorge Puccinefil converso"

BATAILLON, Marcel

1982

Erasmo y España. México, Fondo de Cultura Económica.

BENNASSAL, Bartolomé y Lucile

1992

1492: ¿un mundo nuevo? Madrid, Nerea.

BROWN, Jonathan

1991

La Edad de Oro de la pintura en España. Madrid, Nerea, 2da. ed.

CIEZA DE LEÓN, Pedro de

1967

Señorío de los Incas. Lima, Instituto de Estudios Peruanos, Introd. Carlos Araníbar. 
CHECA, Fernando

1993

Pintura y escultura del Renacimiento en España. Madrid, Ediciones Cátedra.

FERNÁNDEZ ÁLVAREZ, Manuel

1989

La sociedad española en el Siglo de Oro. Madrid, Gredos, 2 da. ed., 2 tomos.

FERNÁNDEZ, Diego "el Palentino"

1876

Primera parte de la Historia del Perú. Lima, edición Manuel de Odriozola, imprenta del estado.

FRANCO, Jean 1982

"La cultura hispanoamericana en la época colonial" En: Iñigo Madrigal, Luis (coord). Historia de la literatura hispanoamericana. T. I. Madrid, Cátedra, (35-53).

GÁLLEGO, Julián 1972

Visión y símbolos en la pintura española del Siglo de Oro. Madrid, Aguilar.

GISBERT, Teresa 1980

Iconografía y mitos indigenas en el Arte, La Paz, Gisbert y Cia.Biblioteca de Letras

GOMBRICH, Ernst "Jorge Puccinelli Converso»

1983

Imágenes Simbólicas. Madrid, Alianza Editorial.

HALL, James

1979

Dictionary of Subjects \& Symbols in Art. New York, Harper \& Row.

HAMPE MARTÍNEZ, Teodoro (comp.)

1999 La tradición clásica en el Perú virreinal. Lima, Fondo Editorial UNMSM, Sociedad Peruana de Estudios Clásicos.

ÍNIGO MADRIGAL, Luis (coord)

1982

Historia de la literatura hispanoamericana. T. I. Madrid, Ediciones S.A. 
LEONARD, Irving A.

1953 Los libros del conquistador, México, FCE.

LOHMANN VILLENA, Guillermo

1999

"Huellas renacentistas en la literatura peruana del siglo XVI" En: HAMPE MARTÍNEZ, Teodoro (Comp.). La tradición clásica en el Perú virreinal. Lima, Fondo Editorial UNMSM, (115-127).

LÓPEZ TORRIJOS, ROSa

1995

La mitología en la pintura española del Siglo de Oro. Madrid, Cátedra.

MENDIBURU, Manuel de 1933

Diccionario histórico-bigráfico. Lima,Imprenta Gil.

NÚN̄EZ, Estuardo

"Henrique Garcés, múltiple hombre del Renacimiento" En: Hampe (Comp. cit) (129-144).

PANOFSKY, Erwin

1970

1985

PEASE G.Y., Franklin

El significado de las Artes Visuales. Buenos Aires, Idea. Madrido Cátedra de Letras 1999

1994

"Temas clásicos en las crónicas peruanas de los siglos XVI y XVII": En: Hampe, Teodoro (Comp.) La tradición clásica en el Perú virreinalUNMSM; SPEC., 17-34.

"La cultura en el Perú en los tiempos de la evangelización". Revista Peruana de Historia Eclesiástica $\mathrm{N}^{\circ} 3$, Cusco, IPHE, (207-217).

PEDRO, Valentín de 1954

América en las letras españolas del Siglo de Oro. Buenos Aires, Editorial Sudamericana.

PIZARRO GÓMEZ, Francisco Javier 1999

Arte y espectáculo en los viajes de Felipe II (1542-1592) Madrid, Ediciones Encuentro. 
RUIZ DE ARCE, Juan

1968

Advertencias que hizo el fundador del vínculo y mayorazgo. Lima, Biblioteca Peruana I.

SERRANO Y SANZ, Manuel

Autobiografias y memorias. Madrid, BAE, № 2, Viaje a Turquía (1-149).

TORRES DE MENDOZA, Luis (Dir.)

1867

Colección de documentos inéditos relativos al descubrimiento,conquista y colonización de las posesiones españolas en América y Oceanía, sacados en su mayor parte del Real Archivo de Indias. Madrid, Imprenta de Frías y compañía.

ZÁRATE, Agustín de 1968

Historia del descubrimiento y conquista del Perú y de las guerras y cosas señaladas en ellas acaecidas hasta... (1551) Lima, Biblioteca Peruana, Editores Técnicos Asociados, T. 2.

\section{Biblioteca de Letras "Jorge Puccinelli Converso"}

